Meta

Journal des traducteurs

Translators' Journal

\title{
Translation from Chinese: Coherence and the Reader
}

\section{Duncan Hunter}

Volume 36, numéro 4, décembre 1991

URI : https://id.erudit.org/iderudit/003160ar

DOI : https://doi.org/10.7202/003160ar

Aller au sommaire du numéro

Éditeur(s)

Les Presses de l'Université de Montréal

ISSN

0026-0452 (imprimé)

1492-1421 (numérique)

Découvrir la revue

Citer cet article

Hunter, D. (1991). Translation from Chinese: Coherence and the Reader. Meta, 36(4), 627-632. https://doi.org/10.7202/003160ar

\section{Résumé de l'article}

En étudiant trois différentes traductions anglaises d'un paragraphe d'un texte chinois, on discute de la difficulté pour les traducteurs de fournir un texte qui soit cohérent pour le lecteur et en même temps fidèle au message de l'auteur. On identifie certaines compétences culturelles que les traducteurs présupposent chez leurs lecteurs pour produire un texte à la fois fidèle et cohérent.
Ce document est protégé par la loi sur le droit d'auteur. L’utilisation des services d’Érudit (y compris la reproduction) est assujettie à sa politique d'utilisation que vous pouvez consulter en ligne.

https://apropos.erudit.org/fr/usagers/politique-dutilisation/ 


\title{
TRANSLATION FROM CHINESE: COHERENCE AND THE READER
}

\author{
DUNCAN HUNTER \\ City Polytechnic of Hong Kong, Hong Kong
}

\begin{abstract}
Résumé
En étudiant trois différentes traductions anglaises d'un paragraphe d"un texte chinois, on discute de la difficulté pour les traducteurs de fournir un texte qui soit cohérent pour le lecteur et en même temps fidèle au message de l'auteur. On identifie certaines compétences culturelles que les traducteurs présupposent chez leurs lecteurs pour produire un texte à la fois fidèle et cohérent.
\end{abstract}

Looking at three English translations (Goldblatt, 1983; Djang, 1986; Barmé, 1982) of the first paragraph of Chapter 4 of Gan Xiao Liu Ji by Yang Jiang (1981), one is immediately made aware of how difficult it is for the translator to establish the right balance between respect for what the author means and respect for what the reader knows. (Please see appendix for translations and original text.) There is little point in translating the text "faithfully" if its message is not communicated to the readers. And translation is, of course, communication, but not at all costs - Newmark (1981) cautions against "the increasing assumption that all translating is (nothing but) communicating, where the less effort expected of the reader, the better... Are they to be handed everything on a plate? Are they to make any effort? Are they ever to be expected to look up a word in a dictionary or an encyclopedia?" Yet, if translators do not take into account the schemas that readers use to derive the implications hidden in the text and to create coherence - "the realisation(s) of the text's meaning potential," as Blum-Kolke (1986) defines it - their translated text may remain as much an enigma for the readers as if it had never been translated. This is especially true when the schemas the readers bring to bear on the text differ from the ones used by the original source language readers. These schemas are informed by the readers' knowledge of the world as they see it, of how things are and should be for them i.e. culture in the widest sense of the term.

It is precisely these differences which translators must be sensitive to when they are translating texts for readers who belong to a very different culture from that of the source language readers. This is the case with English translations of Chinese texts in which the cultural dimension is prominent, exemplified here in Yang Jiang's story of how the dog got its name.

The readers of a translated text may:

a. perceive the selfsame coherence in the text as the original readers because they employ the same, or very similar schemas, to interpret the text;

b. perceive a coherence in the text which is different from that perceived by the original readers;

c. perceive no coherence in the text i.e. the text remains a puzzle. 
Blum-Kolke (1986) suggests that shifts in coherence are the result of either a textbased shift or a reader-based shift. Shifts in coherence can be induced as a result of the translator's deliberate "bending" of the text towards the target audience. This process is informed by what the translator assumes or knows the readership's interpretative schema to be. In other words the translator knows what implications the readers will derive from the text, given the schemas they use to interpret it, and can predict where their schemas will fail them if the original text is translated as though they shared the same schemas as the original readers.

(Needless to say, text-based shifts in coherence may also occur accidentally as a result of mistranslations brought about by the translator's inadequate understanding of the source text.)

Shifts in coherence induced solely by the readers occur when the translator has not "bent" the text towards them and the readers unwittingly interpret the translated text erroneously or, alternatively, find the text enigmatic.

What assumptions do the three translators of Gan Xiao Liu Ji appear to have made about their readers? Readers are of course individuals, each one of whom brings to bear on the translated text unique (but necessarily overlapping) schemas, but to simplify matters we will assume that we are dealing with two categories of readers only: specialists, who know about Chinese language, culture and society, and non-specialists, who do not.

Non-specialist readers confronted with Goldblatt's translation may find themselves formulating a number of questions, as follows:

1. Why do people sometimes misread $\mathrm{Ou}$ as $\mathbf{Q u}$ ?

2. How do you pronounce $\mathbf{Q u}$ ?

3. Does Qu mean Quickie in Chinese?

4. Is the dog's name Little Qu, Quickie, or Little Quickie?

5. Why does the poet need to "get back" at A-Xiang?

6. Why is the name the poet might have called the dog little Xiang and not little A-Xiang?

7. How is Xi pronounced in A-Xiang's name?

8. What does "in the same lineage" mean?

9. Are these people speaking Chinese or English or a mixture of both e.g. little Qu, Quickie, A-qu?

10. Quickie certainly has a better ring to it for us English language readers because (i) it is recognisably English, (ii) pronounceable, but these people are Chinese: why should it have a better ring for them?

These apparently trivial questions arise because the translator appears to have assumed of his non-specialist readers a knowledge of Chinese which is only available to specialist readers. Interestingly, Goldblatt's translation first appeared in the magazine "Renditions", published by the Research Centre for Translation of the Chinese University of Hong Kong and widely read by academics in the field of Chinese studies i.e. by people who know about Chinese language, culture and society, and can answer the questions listed above if in fact they ever arose in their consciousness, so familiar are they with the cultural universe reflected in the text.

Goldblatt's apparent target readers are the specialists. He assumes, or rather, his translation leads one to assume:

a. they are aware of the nature of the Chinese written language and the fact that some characters have more than one pronunciation, depending on the context: in this case $\mathrm{Ou}$ (a family name) and Qu (district, which phonetically is the same as the 
pronunciation of a different character which has several meanings, the most appropriate of which in this context is "hurry").

b. they know how to pronounce a transcription written in hanyu pinyin romanisation (no pronunciation notes are given).

c. they know that the phonetic sequence qu can be realised in two different characters.

d. they know the significance of the prefix A- and why Little A-Xiang would be incorrect.

e. they know that Chinese culture places considerable emphasis on explicitly identifying generational and kinship relations.

f. they appreciate the gentle insult that placing someone in the same lineage as a dog amounts to.

g. they know that Quickie is in fact a (truncated) translation from the original Chinese Xiao Qu (Little Quickie) while A-qu is a transcription from Chinese characters into romanisation and that therefore it is not the word Quickie which was easier to pronounce compared to A-qu but the original Chinese name of which Quickie is an incomplete translation.

Djang, on the other hand, appears to have translated the text on the assumption that his readers are non-specialists who are quite ignorant about:

(i) the nature of the Chinese language;

(ii) the significance of the prefix Ah (A in Goldblatt) in $\mathbf{A h}$ - hsiang;

(iii) the pronunciation of a romanisation written in hanyu pinyin.

He assumes that his readers know what a homonym is, but this is an assumption about their level of English, rather than their familiarity with things Chinese, (they can look the word up in a dictionary) and that they know why naming a person after a dog might be seen as a form of retaliation.

Another factor which makes Djang's text more accessible to the non-specialist is that the romanisation Djang uses is pronounceable for English language readers in a way that the sequences Qu and Xi in Goldblatt's text are not. (The reader may not pronounce Ch' $\ddot{\mathbf{u}}$ or Hsiang in a way recognisable by a native Chinese speaker, but they are "readable" in a way the hanyu pinyin romanisation, in the absence of explanatory notes, is not).

The result is a text which has "face validity" - things are explained in terms of what the non-specialist readers know, and thus appears meaningful. For example, a word in Chinese, such as Ch'ü, can have different meanings, just as an English word can have different meanings. What cannot be explained to an English readership is changed - the cultural component is simply abandoned and a reasonable but (in terms of the original text) incorrect explanation given for appending the prefix Ah-onto the dog's name.

A text such as Djang's is unlikely to raise any questions in the readers' minds because it is, apparently, quite coherent. Interestingly, Djang's translation of Gan Xiao Liu Ji was published in book form in North America for what would appear to be a general non-specialist readership.

Paradoxically, Goldblatt's attempt to respect the original text produces a puzzling message for the non-specialist reader but an interpretable one for the specialist, while Djang's attempt to render the text coherent produces a very clear message for the nonspecialist but at the expense of the source text's original coherence for source language readers. Specialist readers unfamiliar with the original text would also find Djang's text coherent and take it on trust as a competent translation until such time as they became familiar with the original. 
Goldblatt's translation of this particular extract (his translation of the text as a whole is excellent) respects the text but fails to communicate the message to all but the specialists. Djang's translation, on the other hand, fails to respect the text but communicates a message, one which will be read in complete innocence as the message by English language readers, unaware that the text has been "bent" towards them by a "kindly" translator.

Barmé's approach is very similar to Goldblatt's and will raise similar questions in the minds of non-specialist readers. He does attempt to provide information to the readers to help them understand why $\mathbf{O u}$ is mispronounced as $\mathbf{Q u}$ by giving the actual Chinese character - the only one which appears in the text of his translation of the whole book - but in so doing he appears to assume that his readers are aware that Chinese characters map into speech at the morphemic level and not at the phonetic level as with alphabetic letters. This is a big assumption to make about non-specialist readers and his inclusion of this character may be better explained as a reminder to fellow specialists.

Unlike Goldblatt, or indeed Djang, Barmé does not explain the meaning of Qu, so readers may well ask why the poet's revenge should be so "swift and clever" in deciding to use this alternative. However, as Barmé does not translate $\mathbf{Q u}$, and generally uses transcription rather than translation for the various names, readers are not confronted with a mixture of transcription and translation, as in Goldblatt, and the problem of why one name should be more easily pronounceable than the other for the people in the story.

Readers of Barmés translation will also be puzzled by the function of $\mathbf{A}$ which appears either as an integral part of Axiang's name or separated by a hyphen as $\mathbf{A}-q u$, when used in the dog's name, and disappears completely in Xiao? Xiang. They are told it has something to do with being a relative, which is less technical than Goldblatt's explanation that it has to do with "lineage", but the implications have still to be interpreted by the readers themselves.

How important, translators have to ask themselves, is this particular paragraph in the context of the book as a whole? Yang Jiang's book is a record of her life in a cadre school - a euphemism for a rural detention centre where intellectuals were sent during the Cultural Revolution. It is not a book about language per se like, say, Alice's Adventures in Wonderland, in which word play is an integral part of the story, but about the reactions and observations of a Chinese intellectual under house arrest in rural China. Does it therefore matter if the paragraph is modified for a non-specialist readership or not? After all, close textual analysis and comparison are specialist activities and against the text as a whole Goldblatt's translation of this particular extract will constitute no more than a minor obstacle for non-specialist readers who will take it in their stride. For them, what counts is the macro-coherence of the story, as a whole. If they read Djang's translation, this minor, alien obstacle is removed completely by his simple expedient of integrating it, by sleight of translator's hand, into their own world, but is this "bending" of the text an acceptable practice?

As Dickinson (1990) remarks: "Any translation, free or literal, fails to the extent it repels readers as well as to the extent it distorts the writer."

The answer must lie somewhere between these two extremes, (and in judiciously distributed footnotes), so that non-specialists are neither baffled (Goldblatt and Barmé) nor unwittingly misled (Djang):

"The poet in our vegetable team, whose name was Ou, once brought back a little brown puppy from the brick kiln. Now as the character representing the poet's name can be pronounced as $\mathrm{Ou}$, which is just a proper name, or as $\mathrm{Qu}$, which can mean 'hurry', people would occasionally muddle them up, so A-Xiang dubbed the dog Little Qu. Ingeniously, the poet got his own back by counter-naming the dog A-Qu, tagging on the dog's name to the 
beginning of A-Xiang's name as though they were sisters, but as people found the name Little Qu more sayable than Sister Qu, which was what A-qu was meant to imply, the first name stuck. Fortunately no one outside the vegetable team knew that Little Qu was really Little Ou."

\section{PRONUNCIATION NOTES}

$\mathbf{Q}$ as in church; $\mathbf{X i}$ as in Siena

Against the text as a whole this particular extract is now unlikely to raise any queries in the minds of the general reader (specialist or non-specialist). However, taken in isolation and subjected to close scrutiny, it would still raise certain queries in the mind of the discerning reader, who might ask why Chinese readers need to be told the meanings of certain characters, the function of the prefix $\mathbf{A}$, and the motivation behind appending this prefix rather than the word Little to the girl's name - all of which are things they presumably know already. Back translation would reveal further weaknesses: A does not in fact mean either sister or brother, although it could imply that kind of relationship, among others. At this level, discerning readers might conclude, in the belief that the translation was a literal rendition of the original, that the original author had the translator's readership in mind when she wrote the Chinese text, as though she were able to predict (which in fact in real life she could certainly do - Yang Jiang is a respected translator of works from English into Chinese) where the readers' interpretative schema was going to let them down and thwart their efforts to give the text coherence.

In my own rendering I have attempted to make the text as accessible as possible to English language readers without undue distortion of the original. There is, of course, some inevitable distortion (the alternative is heavy footnoting), notably in the addition of explanations: the different pronunciations and meanings of the character $\mathrm{Ou} / \mathrm{Qu}$, and a partial explanation of the function of the prefix $\mathbf{A}$, and the awkward presence of names in romanisation and translation, but at least like is now compared with like i.e. English name ( ittle Qu) with English name (Sister Qu) and an attempt has been made to organise the text to convey, mutatis mutandis, the same order of message to specialist and non-specialist alike.

\section{BIBLIOGRAPHY}

BARMÉ, Geremie (1982): A Cadre School Life Six Chapters, Hong Kong, Joint Publishing Co.

BLUM-KOLKA, Shoshana (1986): "Shifts of Cohesion and Coherence in Translation" in Juliana House and Shoshana Blum-Kulka (Eds.) Interlingual and Intercultural Communication, Tübingen, Gunter Narr, pp. 17-35.

DICKINSON, J.K. (1990): “Ernst Bloch's 'the Principle of Hope': a review of and comment on the English translation," Babel 36.1, pp. 7-31.

DJANG, Chu. (1986): Six Chapters of Life in a Cadre School, Boulder and London, Westview Press.

GOLDBLATT, Howard (1983): Six Chapters from My Life 'Downunder', Hong Kong, Chinese University Press.

NEWMARK, Peter (1981): Approaches to Translation, Oxford, Pergamon Press, p. 51.

YANG, Jiang (1981): Gan Xiao Liu Ji, Hong Kong, Guangjiaojing Publishing Co.

\section{APPENDIX}

\section{TRANSLATIONS AND HANYU PINYIN ROMANISATION}

\section{GOLDBLATT}

One day a poet from our vegetable-plot unit brought a brown puppy over to us from the brick kiln. The poet's name was Ou, which people occasionally misread as Qu. A-Xiang gave the puppy the name Little Qu, or "Quickie". The poet got back at her very cleverly, not by calling the puppy "little Xiang", but by calling her "A-qu", thereby placing the puppy and A-Xiang in the same lineage. But "Quickie" had a better ring to it than 
"A-qu", so that's what we called her. Fortunately, no one outside our vegetable plot detail knew the significance of the name and its relationship to the poet.

\section{DJANG}

The "Pastoral Poct" of our team once brought back a yellow puppy from the brick kiln. The poet's name was Ch'ü, a homonym of the word meaning "run". In a spirit of playfulness, Ah-hsiang named the puppy "Hsiao-ch'ü" or "Little Ch'ü, the Runner" in honour of the poet. To retaliate, the poet wanted to name the dog after Ah-hsiang. In his round-about way he called her "Ah-ch'i"', thus making her share a part of Ah-hsiang's name. But "Hsiao-ch'ü" was easier to pronounce than "Ah-ch' ü", so the former appellation stuck. Few people outside the vegetable team knew that the dog had been named after the poet.

\section{BARMÉ}

Our vegetable brigade poet found a puppy near the kiln and carried it to us in his arms. The poet's surname was $\mathrm{Ou}$ ( $\overline{g_{0}}$ ), and since people sometimes mispronounced it as ' $\mathrm{Qu}$ ', Axiang decided to call the dog Xiao Qu or Little Qu. The poet's revenge was swift and clever: he was not so unimaginative as to suggest that the puppy be called 'Xiao Xiang' after her, but named it 'A-qu' as though it was one of Axiang's relatives. But since Xiao Qu was easier to say, that name stuck. Fortunately, no one outside our brigade ever knew that Xiao Qu had originally been 'Xiao Ou'.

Hanyu Pinyin Romanisation of Chinese text (without tone marks)

Women cai yuan ban de na wei shiren cong zhuanyao li bao hui lai xiao huang gou. Shiren xing $\mathrm{Ou}$. Ou you ren ba xing shi de $\mathbf{O U}$ du ru QU, A- Xiang jiu wei xiao gou mingming Xiao Qu. Shiren de baofu hen miao: ta bu wei xiao gou mingming Xiao Xiang, que yao ta he A-Xiang paihang, jiao ta A-Qu. Keshi Xiao Qu jiao lai bi Xiao Qu shunkou, jiu jiao kai le. Hao zai caiyuan yiwai de ren, bing bu zhidao Xiao Qu yuan shi Xiao Ou.

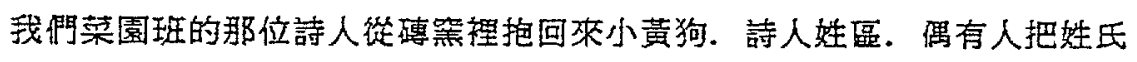
的 [區] 楞如 [超]，阿香就為小狗合名 [小䞶]．詩人的報負很妙：他不為小狗

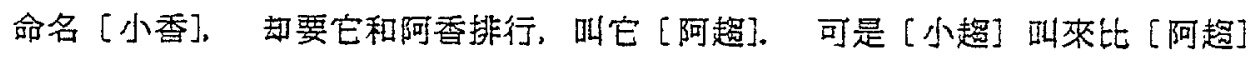
順口，就叫開了．好在萂園以外的人，並不知道 [小䞤 $]$ 原是 [小區 $]$.

\section{（幹校六記 揚絴萻 香港 萲角鏡出版社1981 年)}

